\title{
Endophytic Fungi of Tomato and Their Potential Applications for Crop Improvement
}

\author{
Martina Sinno ${ }^{1, *,+}$, Marta Ranesi ${ }^{1, *,+}$, Laura Gioia $^{1}$, Giada d'Errico ${ }^{1} \mathbb{D}$ and \\ Sheridan Lois Woo $2,3,4$ (D) \\ 1 Department of Agricultural Sciences, University of Naples Federico II, 80055 Portici (NA), Italy; \\ laura.gioia@unina.it (L.G.); giada.derrico@unina.it (G.d.) \\ 2 Department of Pharmacy, University of Naples Federico II, 80131 Napoli, Italy; woo@unina.it \\ 3 Task Force on Microbiome Studies, University of Naples Federico II, 80131 Naples, Italy \\ 4 National Research Council, Institute for Sustainable Plant Protection, 80055 Portici, Italy \\ * Correspondence: martina.sinno@unina.it (M.S.); marta.ranesi@unina.it (M.R.); \\ Tel.: +39-340-928-4138 (M.S.); +39-329-1461-266 (M.R.) \\ + These authors contributed equally to this work.
}

Received: 31 October 2020; Accepted: 25 November 2020; Published: 27 November 2020

\begin{abstract}
Endophytic fungi (EF) are increasingly gaining attention due to the numerous benefits many species can offer to the plant host, while reducing the application of chemicals in agriculture, thus providing advantages to human health and the environment. The growing demand for safer agrifood products and the challenge of increasing food production with a lower use of pesticides and fertilizers stimulates investigations on the use and understanding of EF. Other than direct consequences on the plant damaging agents, these microorganisms can also deliver bioactive metabolites with antimicrobial, insecticidal, or plant biostimulant activities. In tomato, EF are artificially introduced as biological control agents or naturally acquired from the surrounding environment. To date, the applications of $\mathrm{EF}$ to tomato has been generally limited to a restricted group of beneficial fungi. In this work, considerations are made to the effects and methods of introduction and detection of EF on tomato plants, consolidating in a review the main findings that regard pest and pathogen control, and improvement of plant performance. Moreover, a survey was undertaken of the naturally occurring constitutive endophytes present in this horticultural crop, with the aim to evaluate the potential role in the selection of new beneficial EF useful for tomato crop improvement.
\end{abstract}

Keywords: endophytes; biocontrol; biostimulants; induced systemic resistance; ISR; plant pathogens; fungal entomopathogens

\section{Introduction}

Different approaches can be used to discover alternatives to chemical pesticides, to prevent or control harmful plant biotic agents. In recent years, the interest in the biological control of plant pests and pathogens has surged to meet the requirements for more environmentally friendly options to synthetic chemicals. Consequently, the method for the use of microbial biological control agents (mBCAs), as natural antagonists to suppress herbivores and organisms that cause disease, has increased and improved. Fungi are among the most important mBCAs selected for this application due to their ease of isolation, selection from a vast number of known non-pathogenic strains, morphological structures for conservation and delivery, adaptation to numerous engineering fermentation technologies in industry, manageability in formulations, as well as their capability to secrete and over-express endogenous proteins or nontoxic exogenous compounds [1]. Furthermore, many beneficial fungi are 
known to promote plant growth and act as plant biostimulants or biofertilizers, thus their application in agriculture may also reduce the use of chemical fertilizers [2].

Among the plant favorable fungi, fungal endophytes, in particular, have been gaining increased attention because of the numerous benefits they can offer directly to the plant host with the intimate interaction established during the colonization of the plant tissues [3-7]. Since their discovery, endophytes have been isolated from different vegetative structures, many diverse plant species, both in natural uncultivated, as well as in agricultural environments [8]. These endophytic fungi (EF) represent a microbial community with an enormous reserve of biodiversity, originating from diverse ecological niches and host tissues ranging from the algae living in marine environments [9] to trees in the forest ecosystems [10].

These microorganisms have the ability to colonize plants without causing any symptoms [11], establishing a plant-fungi association inside the living plant tissue, that may occur within roots, stems, and/or leaves, and they emerge from the plant tissue only at the time of sporulation or upon senescence of the host [12-14]. The fossil record indicates that plants have had associations with endophytic [15] and mycorrhizal [16] fungi for more than 400 million years, a relationship that has likely existed since the time when plants first colonized land, thus playing a long and important role in the driving force of evolution, and life on land. In recent decades, scientific evidence has demonstrated that non-pathogenic microbes, endo- or exo-inhabitants of plants, may be associated with latent pathogens or early colonizing saprophytes that could actively grow in the living vegetative tissues only at the moment that plant defense responses waned or the plant initiated the phase of senescence [17]. The specific interaction between the host plant and its microbial partners ranges on a continuum from neutralism towards mutualism and antagonism, in which the nature of the relationship may change during the lifecycle of the plant depending upon environmental as well as intrinsic factors [18-20].

Currently, the concept of the plant microbiome considers a viewpoint on plant-microbe evolution, in which the plant and the microbiota have evolved together, with the microorganisms providing advantages and versatility to the plant in its ecosystem: an exchange of the plant as a habitat and source of nutrition, with some endophytic microorganisms producing benefits to the host plant that include the stimulation of growth and development, adaptation to the environment and abiotic stress tolerance [21,22]. More recently, it has been reported that EF can also have a protective role against attack by insects [23], pathogens [24], and nematodes [25], thus acting as multiple plant defenders or biocontrol agents.

Like most of the beneficial fungi, EF are known to secrete a vast number of bioactive secondary metabolites that are primarily responsible for the observed useful effects since they can stimulate the plant defense response and growth, as well as exert a direct antimicrobial or insecticidal effect [2,26-28]. Indeed, the remarkable advantage of these microorganisms is due to the in-depth relationship within the plant host that allows the immediate availability of the secreted active molecules within plant tissues $[28,29]$. In a broad sense, $\mathrm{EF}$ are producers of bioactive metabolites for which the plant constitutes a delivery system; in the case of insecticidal or antimicrobial molecules, the plant serves as a pipeline for the translocation of these compounds to the target pathogen or pest, thus EF act as a biopesticide [29,30].

Tomato belongs to the Solanaceae family, and it is one of the most commonly cultivated vegetable crops worldwide. Solanum section Lycopersicon includes the cultivated tomato (Solanum lycopersicum L.) and 12 additional wild relatives, but S. lycopersicum is the only domesticated species [31]. The tomato originated from South America, then spread globally through different levels of domestication, starting prior to the 15th century and continuing into Europe, arriving to its present status as one of the most highly consumed food crops of international acclaim. In 2018, the global tomato production reached more than 180 million tons, in which the cultivated area worldwide of harvested tomatoes accounted for almost 5 million ha (FAOSTAT 2018). Due to its extensive global distribution and consumption, tomato is one of the most important horticultural crops farmed, and during its cultivation, it is constantly threatened by pests and pathogens. In recent times, the use of chemical pesticides is 
becoming largely restricted in agriculture both due to the negative impact on human health and the environment (EU Directive 2009/128/CE), plus the risks of resistance development in pathogen/pest populations by their use.

The growing demand by consumers for safer food products plus the urgent challenge of increasing food production with lower inputs of pesticides and fertilizers stimulates both the utilization of EF as non-chemical plant beneficials, as well as the investigations that provide further insights into the interactions of these microorganisms with the crop host and the organisms that damage it. Recent studies have focused on the use of EF in protecting and improving tomato crop as an alternative to the chemical approach for crop protection (references in this review). The presence of $\mathrm{EF}$ in tomato can be prevalent in the plant if the fungi were introduced as mBCAs, or if the EF were naturally acquired from the surrounding environment and horizontally and/or vertically transmitted into the plant [32]. According to the increasing interest in this argument, the present paper offers a review of the principle $\mathrm{EF}$ that have been introduced to tomato for the biological control of various pests and pathogens, plus those applied to improve the plant performance, growth/yield, and quality. Furthermore, a section of this review is dedicated to constitutive EF isolated and identified from tomato, which can serve as a valuable source of new microbial beneficial applications with unexplored potential to improve the production of tomato and other crops.

\section{Beneficial Effects of EF Introduction on Crops}

The beneficial effects executed by EF include pest and pathogen control, plant growth promotion (PGP), improvement of the plant nutrient availability and uptake, and the increased tolerance to abiotic stress, hereby referred to as plant physiology improvement (PPI). EF have been confirmed to affect insect pests feeding on the plants that they colonize [23,33-35], and results in the literature indicated that these microorganisms provided protection from significant herbivory damage they cause to crops. Insect pests have been noted to be affected by EF in numerous ways such as reduction of developmental rate [36,37], deterrence of feeding on the colonized plant [38,39], retarded insect growth, higher mortality, and lower oviposition [40,41]. One of the hypothesized mechanisms underlying these effects is the bioaccumulation of secondary metabolites and mycotoxins produced by the EF within the plant tissues [34]. Moreover, these microorganisms are known to defend their plant host from pathogens attack [3-7]. This biocontrol action could be exerted through direct mechanisms including food and space competition, parasitism, and antibiosis [39,42-44]. While colonizing host plants, EF stimulate the attacked plant to create a barrier (biochemical or mechanical) that inhibits pathogenic organisms from penetrating the same tissue hence preventing the occurrence of diseases [45]. An important indirect mechanism involved in plant protection is the induction of plant resistance which is implemented by the alteration of the biochemical signaling pathways of the plant that modulate the resistance-related genes which are triggered by the endophytic colonization [46-51]. PGP implemented by EF is characterized by the improvement of the above- and/or below-ground biomass [52-54] while PPI effects include the increase of nutrients uptake, particularly nitrogen and phosphorus [55,56], and enhanced tolerance to abiotic stress including drought, salt, and heat [1]. EF can be, thus, utilized as biofertilizers as they improve the nutrient uptake firstly enhancing the plant root system and secondly, in the case of entomopathogenic endophytes, reallocating the insect-derived nitrogen to the host plant. In fact, EF, after feeding on insects in the rhizosphere, may translocate the adsorbed nitrogen to the host plant towards the association with the root system [55].

\section{Introduced Endophytes of Tomato}

The utilization of EF as biological control agents (BCA) represents a potential alternative that meets the growing need for more eco-sustainable agriculture. According to this new perspective, in recent years many studies have been performed, introducing EF on tomato to test their effects on plant performance. Among these introduced EF, a consistent number of species belongs to a group of fungi classified as entomopathogens, fungi that are pathogens to insects, many isolated from asymptomatic plants, 
including Akanthomyces spp., Beauveria bassiana, Clonostachys rosea, Cordyceps farinosa (formerly Isaria farinosa), Lecanicillium spp., and Sarocladium spp. (formerly Acremonium spp.) [39,57-61]. The natural occurrence of these fungi within the plant tissues suggests their ability to endophytically colonize a wide range of plants.

To date, in tomato as for many other horticultural crops, the artificial introduction of EF has been limited to a restricted group of beneficial microbes which include species belonging to the genus Sarocladium, Beauveria, Metarhizium, Fusarium, Penicillium, Serendipita (formerly Piriformospora), Pochonia, Pythium, and Trichoderma [36,37,62-68]. Furthermore, some introduced species belong to the Dark Septate Endophytes (DSE) such as Neocosmospora haematococca (formerly Nectria haematococca) and Periconia spp. DSE represent a large group of root-inhabiting endophytes not yet well defined taxonomically and/or ecologically that are distinguished as a functional group based on the presence of darkly melanized septa. DSE are ubiquitous and abundant in various ecosystems and playing an interesting role in contrasting pathogens as they can improve plant tolerance to abiotic stress [69], growth [70], and nutrient uptake [71]. In short, DSE may play an important role in the ecophysiology of plants. However, almost a century after their discovery, little is still known about the role of these mysterious and rather elusive fungal symbionts.

\subsection{Biocontrol}

The biocontrol of pests and pathogens has been the most documented beneficial effect explicated by the artificial introduction of endophytic fungi to tomato. In this context, 41 scientific papers report the use of mBCAs that focuses on crop protection and the consequences on the organisms that are deleterious to tomato (Table 1).

In particular, concerning the insect pests, biocontrol potential of EF was evidenced for the negative effects on Aphis gossypii [72], Bemisia tabaci [73,74], Chortoicetes terminifera [72], Helicoperva armigera [75,76], Nesidiocoris tenuis [77], Spodoptera exigua [78], S. littoralis [23], Tuta absoluta [79,80], and Trialeurodes vaporariorum [43]. Furthermore, Neocosmospora solani (formerly Fusarium solani) increased tomato defense against infestations of the red spider mite, Tertranychus urticae [46], while several endophytic species were able to induce resistance to the root-knot nematode Meloidogyne incognita [25,81-83]. The overall effects observed on tomato pests included: increased mortality, feeding deterrence, reduced growth rate and reproduction, reduced infestation, egg masses colonization, and increased plant defense.

Regarding disease control, EF were reported to counteract the infection of the bacterial pathogen Clavibacter michiganensis subsp. michiganensis [84], fungal pathogens Fusarium oxysporum f. sp. lycopersici [84-92], Rhizoctonia solani [93] and Botrytis cinerea [42,94]. In the above-mentioned papers, the reported effects of endophytic colonization on pathogen control were noted with reduced disease symptoms and a disease-suppressive effect.

In most papers, the authors suggested that the reduced impact of pests and diseases was due to plant resistance induced by its microbial partner. The mechanism underlying this induced resistance are subdivided into two main categories: Systemic Acquired Resistance (SAR) and Induced Systemic Resistance (ISR). SAR is induced by the plant local infection by latent pathogens and is effective against a broad range of harmful plant biotic agents, it is mediated by salicylic acid (SA) and associated with pathogenesis-related proteins [95]. This is the case of N. solani strain Fs-K which was reported to induce plant resistance against Septoria lycopersici through a SAR mechanism [87]. On the other hand, ISR is triggered by the endophytic colonization of beneficial microorganism such as plant growth-promoting rhizobacteria and EF that involves a priming process of the plant which results in more efficient activation of its defense responses against pests and pathogens [96]. It is mediated by jasmonic acid (JA) and ethylene (ET) [97]. This is the case of Trichoderma hamatum which is reported to induce resistance against the tomato bacterial spot caused by Xanthomonas euvesicatoria [98]. Nonetheless, SAR and ISR may be two distinct but overlapping mechanisms as a result of crosstalk of the two hormonal pathways [97], as noted for Trichoderma harzianum which induced plant resistance against M. incognita through priming plant defense with both SA and JA stimulation [99]. 


\subsection{Plant Growth Promotion and Plant Physiology Improvement}

Plant growth promotion of tomato attributed to endophytic colonization has been well-documented (Table 1). Thirteen studies have indicated that there was evident PGP as demonstrated by the improvement of the root system with greater root length, biomass, and dry weight $[69,83,88,94,100-102]$, increased plant height, shoot biomass, and fresh or dry weight $[69,70,83,88,89,100,101]$, plus enhanced plant production with anticipated flowering and fruiting times, and increased fruit weight [102].

Moreover, a few articles reported improvement of the plant nutrient uptake and the increased tolerance to abiotic stress (PPI) (Table 1). Improved plant uptake of iron (Fe) [103], organic nitrogen (N) [70,71], and inorganic potassium (K) [70], have been demonstrated to be a consequence of the plant endophytic colonization with some fungal species namely B. bassiana, Periconia macrospinosa (DSE) plus an unidentified species also belonging to DSE. Additionally, some studies have highlighted that the presence of the endophyte confers tolerance to diverse abiotic stress such as drought [69], salinity [104], and metals [101].

Table 1. Effects of introduced fungal endophytes on tomato plants in terms of Plant Growth Promotion (PGP) and Plant Physiology Improvement (PPI), and Biocontrol (BC) of pest and pathogens.

\begin{tabular}{|c|c|c|}
\hline \multirow{2}{*}{ Fungal Species } & \multicolumn{2}{|r|}{ Effects } \\
\hline & PGP and PPI & BC \\
\hline Sarocladium strictum * & & Increased mortality of larvae of Trialeurodes vaporariorum [105] \\
\hline \multirow[t]{6}{*}{ Sarocladium kiliense * } & $\begin{array}{l}\text { Increased number of xylem vessels within the } \\
\text { shoots [84] }\end{array}$ & $\begin{array}{l}\text { Reduced symptoms caused by Fusarium oxysporum f. sp. lycopersici and } \\
\text { Clavibacter michiganensis subsp. michiganensis [84] }\end{array}$ \\
\hline & & ISR vs. Rhizoctonia solani [93] \\
\hline & & ISR vs. Botrytis cinerea [42] \\
\hline & & ISR vs. F. oxysporum f. sp. lycopersici [85] \\
\hline & & Increased mortality of Tuta absoluta $[79,80]$ \\
\hline & & $\begin{array}{l}\text { Reduced incidence of Fusarium oxysporum } \mathrm{f} \text {. sp. lycopersici and Helicoverpa } \\
\text { armigera [106] }\end{array}$ \\
\hline \multirow[t]{6}{*}{ Beauveria bassiana } & Enhanced terpene production [78] & Increased mortality of Helicoperva armigera $[75,106]$ \\
\hline & & Increased mortality of Bemisia tabaci [73] \\
\hline & & Feeding deterrent for Bemisia tabaci [74] \\
\hline & & Increased mortality of Spodoptera littoralis [23] \\
\hline & & Reduced growth rate of Spodoptera exigua [78] \\
\hline & & $\begin{array}{l}\text { Reduced reproduction of Aphis gossypii and reduced growth rate of } \\
\text { Chortoicetes terminifera [72] }\end{array}$ \\
\hline \multirow[t]{2}{*}{ Metarhizium anisopliae } & $\begin{array}{c}\text { Increased plant height, root length, shoot and root } \\
\text { dry weight [100] }\end{array}$ & Increased mortality of Spodoptera littoralis [23] \\
\hline & & $\begin{array}{l}\text { ISR vs. F. oxysporum f. sp. lycopersici [86] } \\
\text { ISR vs. Meloidogyne incognita [81,82] }\end{array}$ \\
\hline Fusarium oxysporum & & Fermentation broth with anti-oomycete activity vs. Pythium ultimum, \\
\hline & & Phytophthora infestans and Phytophthora capsici [24] \\
\hline \multirow{5}{*}{ Neocosmospora solani ${ }^{*}$} & & Reduced infestation of Trialeurodes vaporariorum [42] \\
\hline & & ISR vs. Nesidiocoris tenuis [77] \\
\hline & & ISR vs. F. oxysporum f.sp. radicis-lycopersici [87] \\
\hline & & SAR vs. Septoria lycopersici [87] \\
\hline & & Increased tomato defenses against Tertranychus urticae [107] \\
\hline Fusarium spp. & $\begin{array}{l}\text { Increased roots length, shoots height and plant fresh } \\
\text { weight [88] }\end{array}$ & ISR vs. Fusarium oxysporum f. sp. radicis-lycopersici [88] \\
\hline $\begin{array}{l}\text { Neocosmospora haematococca * } \\
\text { (DSE) }\end{array}$ & $\begin{array}{c}\text { Drought stress tolerance, improved plant growth, } \\
\text { and proline accumulation [69] }\end{array}$ & \\
\hline Unidentified (DSE) & $\begin{array}{l}\text { Increased aboveground plant dry biomass and } \\
\text { increased uptake of organic } \mathrm{N} \text { and inorganic K [70] }\end{array}$ & \\
\hline \multirow{3}{*}{ Penicillium simplicissimum * } & Salinity stress tolerance [104] & \\
\hline & Metal stress tolerance [101] & \\
\hline & $\begin{array}{l}\text { Increased shoot length and biomass under normal } \\
\text { and Al stress conditions [101] }\end{array}$ & \\
\hline \multirow[t]{2}{*}{ Periconia macrospinosa (DSE) } & $\begin{array}{l}\text { Improved organic } N \text { uptake and plant biomass } \\
\text { when organic nutrients are present [71] }\end{array}$ & \\
\hline & Increased fresh weight [89] & ISR vs. Tomato yellow leaf curl virus [109] \\
\hline Serendipita indica* & $\begin{array}{l}\text { Accelerated vegetative and generative } \\
\text { development [108] }\end{array}$ & $\begin{array}{l}\text { Disease-suppressive effect vs. Verticillium dahliae and F. oxysporum [89-91] } \\
\text { Reduced infestation of Meloidogyne incognita [25] }\end{array}$ \\
\hline Pochonia chlamydosporia & $\begin{array}{l}\text { Increased root and shoot growth [83] } \\
\text { Anticipated flowering and fruiting times, increased } \\
\text { fruit weight and root growth [102] }\end{array}$ & Colonizes egg masses of Meloidogyne incognita [83] \\
\hline Pythium oligandrum & & $\begin{array}{l}\text { ISR vs. Ralstonia solanacearum [110] } \\
\text { ISR vs. Fusarium oxysporum f. sp. lycopersici [92] } \\
\text { ISR vs. B. cinerea [111] }\end{array}$ \\
\hline Trichoderma atroviride & $\begin{array}{l}\text { Increased root and shoot growth depending on the } \\
\text { tomato } \mathrm{cv}[94]\end{array}$ & $\begin{array}{c}\text { Reduced infestation of Trialeurodes vaporariorum [43] } \\
\text { ISR vs. Botrytis cinerea [94] }\end{array}$ \\
\hline Trichoderma hamatum & & ISR vs. Xanthomonas euvesicatoria (tomato bacterial spot) [98] \\
\hline Trichoderma harzianum & $\begin{array}{l}\text { Increased root and shoot growth depending on the } \\
\text { tomato } \mathrm{cv}[94]\end{array}$ & $\begin{array}{c}\text { ISR and SAR vs. Meloidogyne incognita [99] } \\
\text { ISR vs. Botrytis cinerea [94] } \\
\text { Reduced desease symptoms caused by Alternaria solani and Phytophtora } \\
\text { infestans [112] }\end{array}$ \\
\hline
\end{tabular}

* scientific names are different from those present in the articles cited due to taxonomic updates to the name presently use. 


\subsection{Methods of Introduction and Detection}

In the last decades, it has been demonstrated that several beneficial EF can be artificially introduced on tomato using different inoculation methods and numerous protocols have been developed to successfully achieve this colonization, as well as to detect the fungi within the plant tissues. The methods used for the introduction and detection of EF in tomato plants are summarized in Table 2. The inoculation of EF to tomato plants is mainly achieved with conidial suspension applied by seed treatments, root dipping, soil watering, stem injection, and leaf spraying. Alternatively, the application can be performed by mixing fungal biomass with the transplanting soil. Among the different inoculation techniques, the soil applications, mainly by watering with a conidia suspension, was the most commonly and successfully used technique applied in 18 studies. This was followed by the treatment of seed, as adopted in 15 studies, which was performed by various methods including seed soaking, seed coating, and seed dressing. Seed soaking consisted of placing the tomato seeds in a liquid conidial suspension for 2 to $24 \mathrm{~h}$, before planting. Seed coating involved immerging the seeds in a conidial suspension, stirring them every $30 \mathrm{~min}$ for $2-3 \mathrm{~h}$, to cover and adhere the spores to the seed surface, then successively air-drying under sterile conditions $[93,94,113]$. Seed dressing, was the less common technique, preparing and mixing the seeds in a conidia suspension with continuous shaking for several hours $[74,103]$. The conidia suspension usually contained a "sticker" such as Tween 80 $(0.1-0.01 \% v / v)$ or methylcellulose $(5-10 \% v / v)$, to ensure a more efficient adhesion of the conidia to the seed surface. Root dipping was another technique commonly used that consisted of dipping the seedling roots in a conidial or propagule suspension for 6 to $24 \mathrm{~h}$ prior to transplant $[71,76,79,89,106,110]$.

It is evident that the methods of application were numerous, and the selection of the most efficient method is highly dependent on the specific EF that is employed. The majority of the studies, involving the artificial introduction of EF to tomato, were conducted in a controlled environment, usually with sterilized soil or transplanting substrate, and not in the open field, in order to facilitate the monitoring of the plant colonization. The field application of EF is a challenge that needs to take into account the enormous variability of the environment that could negatively affect the efficacy of the above-mentioned protocols for the introduction. Another critical issue is represented by the transient nature of some endophytes in plant colonization, which explains why, in most cases, the studies do not report details on the time duration of the endophytic colonization. A study by Resquin-Romero [23] indicated that the endophytic colonization of the plant was transient and that the EF-plant interaction was lost after a certain period of time after inoculation. Due to the transient nature of the endophytic colonization, as has been documented in other crops, it is recommended that parallel time-course studies should be performed to monitor the extent of endophytic development, for example, with molecular, microscopy, and/or in vivo re-isolation techniques [68,114-119]. This attests to the difficulty of establishing stable and lasting interactions between the chosen endophyte and its plant host, in the attempt to obtain the potential desired effect.

To ensure that the inoculation of the fungal species is followed by actual endophytic colonization of the plant, it is mandatory to include an experimental stage to detect the EF within the plant. Out of the 52 papers reviewed, 16 studies did not include an endophyte detection assay in their experimental workflow. It is recommended that an analysis of the EF presence should always be included in the study in order to assess the success of the endophytic colonization of the plant, plus monitor the rate of colonization. Moreover, this detection stage should follow an accurate surface-sterilization of the plant tissues to avoid the inadvertent isolation of epiphytic rather than endophytic fungi.

The methods to determine the presence of EF can be divided into three main types: the re-isolation of the EF from the plant tissue, the molecular detection by polymerase chain reaction (PCR), and morphological observation using microscopy techniques. Each method requires the sterilization of the plant material to eliminate the epiphytic microbial community, usually obtained by dipping the tissue in a diluted bleach solution for 1-3 min, that can be followed or proceeded with a brief $70 \%$ ethanol bath, completed with rinsing it at least three-times with sterile water. As a check of the efficacy 
of the sterilization procedure, aliquots of the rinsed water are also plated, and if bacterial or fungal growth occurs the sample is discarded.

The re-isolation of the fungal colony from the host plant tissue is the most used method to assess the endophytic colonization and is reported in 17 studies. Usually, it follows this protocol: collect, wash, and sterilize the plant material, dissect the vegetal tissues in $1 \mathrm{~cm}$ pieces under sterile conditions, and place the pieces on Petri dishes containing solid culture substrate. Most of the authors utilized potato dextrose agar (PDA), supplemented with antibiotics to avoid bacterial contaminations, while others used selective media for the specific EF they were interested in re-isolating $[23,80,100,120]$. Molecular analysis was also widely used for the identification of the EF and is reported in 12 studies. It was based on the extraction of the DNA from the pre-sterilized plant tissue, and the subsequent amplification by PCR and sequencing of amplicons for specific fungal molecular markers such as the Internal Transcribed Spacer (ITS1 and ITS2) region and the translation elongation factor (TEF). Five manuscripts included the quantitative detection of the EF within the plant tissue using a real-time PCR $[77,86,87,107,121]$.

Eleven studies used microscopy techniques to visually examine the fungal presence within the plant tissues. These techniques included light optical microscopy using stained plant tissues, usually with trypan blue or methyl blue, scanning electron microscope (SEM), and transmission electron microscope (TEM). The microscope analysis was particularly valuable for observing and understanding the EF growth distribution patterns and translocation within the plant tissues, thus providing important information and a deeper insight of the EF colonization that was not possible in comparison to the other methods with the re-isolation or molecular detection.

Table 2. Methods of introduction and detection of fungal endophytes in tomato plant with relative cultivar.

\begin{tabular}{|c|c|c|c|c|c|}
\hline Fungal Species & Tomato Cultivar & $\begin{array}{l}\text { Method of EF } \\
\text { Inoculation }\end{array}$ & Detection Method & $\begin{array}{l}\text { Location of EF in } \\
\text { Plant Tissues }\end{array}$ & Ref. \\
\hline Sarocladium kiliense * & $\begin{array}{l}\text { Haubner's } \\
\text { Vollendung }\end{array}$ & $\begin{array}{l}\text { Fungal biomass } \\
\text { mixed with } \\
\text { transplanting soil }\end{array}$ & & Roots & [84] \\
\hline S. strictum * & $\begin{array}{l}\text { Haubner's } \\
\text { Vollendung }\end{array}$ & Soil watering & $\begin{array}{l}\text { Re-isolation from the } \\
\text { plant tissue on PDA }\end{array}$ & Roots & [105] \\
\hline S. strictum * & Suso RZÒ F1 hybrid & Soil watering & $\begin{array}{l}\text { Re-isolation from the } \\
\text { plant tissue on MEA }\end{array}$ & Roots & [122] \\
\hline Beauveria bassiana & Platense & $\begin{array}{l}\text { Seed soaking } \\
\text { Leaf spraying } \\
\text { Root dipping }\end{array}$ & $\begin{array}{l}\text { Re-isolation from the } \\
\text { plant tissue on PDA }\end{array}$ & Leaves & [79] \\
\hline B. bassiana & Mobil & Seed coating & $\begin{array}{l}\text { Re-isolation from the } \\
\text { plant tissue on PDA }\end{array}$ & & [93] \\
\hline B. bassiana & Limachino-INIA & $\begin{array}{l}\text { Fungal biomass } \\
\text { mixed with } \\
\text { transplanting } \\
\text { substrate }\end{array}$ & $\begin{array}{l}\text { Re-isolation from the } \\
\text { plant tissue on Noble } \\
\text { agar }\end{array}$ & $\begin{array}{l}\text { Roots } \\
\text { Stem } \\
\text { Leaves }\end{array}$ & [42] \\
\hline B. bassiana & Rio Fuego & $\begin{array}{l}\text { Soil watering } \\
\text { Leaf spraying } \\
\text { Stem injection }\end{array}$ & & & [85] \\
\hline B. bassiana & $\begin{array}{c}\text { Ace, Early Pack, } \\
\text { Money Maker, Peto } \\
\text { 86, Prichard, Pusa } \\
\text { Ruby, Strain B and } \\
\text { LA1478 }\end{array}$ & $\begin{array}{l}\text { Leaf spraying } \\
\text { Stem injection }\end{array}$ & PCR & Stem & [73] \\
\hline B. bassiana & Grosse lisse & Leaf spraying & $\begin{array}{l}\text { Re-isolation from the } \\
\text { plant tissue on PDA }\end{array}$ & Leaves & [34] \\
\hline B. bassiana & Harzfeuer F1 & Leaf spraying & $\begin{array}{l}\text { Re-isolation from the } \\
\text { plant tissue on } \\
\text { selective media }\end{array}$ & Leaves & [80] \\
\hline B. bassiana & Regina & $\begin{array}{l}\text { Conidial suspension } \\
\text { on wounded rachis }\end{array}$ & $\begin{array}{l}\text { Re-isolation from the } \\
\text { plant tissue on } \\
\text { selective media }\end{array}$ & Roots & [120] \\
\hline
\end{tabular}


Table 2. Cont.

\begin{tabular}{|c|c|c|c|c|c|}
\hline Fungal Species & Tomato Cultivar & $\begin{array}{l}\text { Method of EF } \\
\text { Inoculation }\end{array}$ & Detection Method & $\begin{array}{l}\text { Location of EF in } \\
\text { Plant Tissues }\end{array}$ & Ref. \\
\hline B. bassiana & $\begin{array}{l}\text { Cal-J, Kilele F1, } \\
\text { Anna F1 }\end{array}$ & Seed soaking & $\begin{array}{l}\text { Re-isolation from the } \\
\text { plant tissue on SDA }\end{array}$ & $\begin{array}{l}\text { Roots } \\
\text { Stem } \\
\text { Leaves }\end{array}$ & [123] \\
\hline B. bassiana & Cal-J, Kilele, Anna & Seed soaking & $\begin{array}{l}\text { Re-isolation from the } \\
\text { plant tissue on SDA }\end{array}$ & $\begin{array}{l}\text { Roots } \\
\text { Stem } \\
\text { Leaves }\end{array}$ & [124] \\
\hline B. bassiana & Mountain Spring & $\begin{array}{l}\text { Seed coating } \\
\text { Seed soaking }\end{array}$ & & & [113] \\
\hline B. bassiana & PKM1 & $\begin{array}{l}\text { Root dipping } \\
\text { Soil watering }\end{array}$ & & & [76] \\
\hline B. bassiana & PKM1 & $\begin{array}{l}\text { Seed soaking } \\
\text { Root dipping } \\
\text { Root dipping }\end{array}$ & & & [106] \\
\hline B. bassiana & surahi & $\begin{array}{l}\text { Stem injection } \\
\text { Soil inoculum } \\
\text { Leaf spray }\end{array}$ & $\begin{array}{l}\text { Re-isolation from the } \\
\text { plant tissue on PDA }\end{array}$ & Leaves & [75] \\
\hline B. bassiana & Tres Cantos & Leaf spray & $\begin{array}{l}\text { Re-isolation from the } \\
\text { plant tissue on } \\
\text { selective media }\end{array}$ & $\begin{array}{l}\text { Stem } \\
\text { Leaves }\end{array}$ & [23] \\
\hline B. bassiana & $\begin{array}{l}\text { Marmande- } \\
\text { Cuarenteno }\end{array}$ & Seed soaking & $\begin{array}{l}\text { Re-isolation from the } \\
\text { plant tissue on SDCA }\end{array}$ & $\begin{array}{l}\text { Stem } \\
\text { Leaves } \\
\text { Roots }\end{array}$ & [35] \\
\hline B. bassiana & Castlemart & $\begin{array}{l}\text { Seed coating } \\
\text { Leaf spray }\end{array}$ & PCR & Shoot & [78] \\
\hline B. bassiana & Hezuo 903 & $\begin{array}{l}\text { Root irrigation } \\
\text { Reed dressing }\end{array}$ & PCR & Shoot & [74] \\
\hline Fusarium spp. & Rio Grande & Soil watering & PCR & $\begin{array}{l}\text { Root } \\
\text { Stem }\end{array}$ & [88] \\
\hline F. oxysporum & Montfavet 63-5 & Root application & Real-Time qPCR & $\begin{array}{c}\text { Roots } \\
\text { Cotyledons }\end{array}$ & [86] \\
\hline F. oxysporum & Furore & Soil application & & Roots & [81] \\
\hline F. oxysporum & Moneymaker & Soil watering & & Roots & [82] \\
\hline F. oxysporum & $\begin{array}{l}\text { Hellfrucht/JW } \\
\text { Frühstamm }\end{array}$ & Soil watering & & Roots & [43] \\
\hline Neocosmospora solani ${ }^{*}$ & Pearson & Soil watering & Real-Time qPCR & Roots & [77] \\
\hline N. solani * & Ace 55 & Soil watering & Real-Time qPCR & Roots & [107] \\
\hline N. solani* & Ace 55 & Soil watering & $\begin{array}{c}\text { Microscopy } \\
\text { Real-Time qPCR }\end{array}$ & Roots & [87] \\
\hline Metarhizium anisopliae & Hybrid var. 8625 & Soil watering & $\begin{array}{l}\text { Re-isolation from the } \\
\text { plant tissue on } \\
\text { selective media }\end{array}$ & $\begin{array}{l}\text { Roots } \\
\text { Shoots } \\
\text { Leaves }\end{array}$ & [100] \\
\hline M. anisopliae & Tres Cantos & Leaf spray & $\begin{array}{l}\text { Re-isolation from the } \\
\text { plant tissue on } \\
\text { selective media }\end{array}$ & $\begin{array}{c}\text { Stem } \\
\text { Leaves }\end{array}$ & [23] \\
\hline M. brunneum & Ruthje & $\begin{array}{c}\text { Encapsulated } \\
\text { mycelial biomass }\end{array}$ & $\begin{array}{l}\text { Light microscopy } \\
\text { Real-Time qPCR }\end{array}$ & Stem & [121] \\
\hline $\begin{array}{c}\text { Neocosmospora } \\
\text { haematococca }^{*}(\mathrm{DSE})\end{array}$ & $\mathrm{CO}-2$ & $\begin{array}{l}\text { Soil application of } \\
\text { mycelial biomass } \\
\text { formulation }\end{array}$ & Light microscopy & Roots & [69] \\
\hline Unidentified (DSE) & Santa Clara I-5300 & $\begin{array}{l}\text { Soil application of } \\
\text { mycelial biomass }\end{array}$ & Light microscopy & Roots & [70] \\
\hline $\begin{array}{c}\text { Penicillium } \\
\text { semplicissimum * }\end{array}$ & LA2710 & $\begin{array}{l}\text { Soil application of } \\
\text { mycelia and culture } \\
\text { filtrate }\end{array}$ & & Roots & [101] \\
\hline $\begin{array}{c}\text { Periconia macrospinosa } \\
\text { (DSE) }\end{array}$ & Hildares F1 & $\begin{array}{l}\text { Root dipping in } \\
\text { propagule suspension }\end{array}$ & Light microscopy & Roots & [71] \\
\hline Serendipita indica * & Hildares & Root dipping & $\begin{array}{l}\text { Re-isolation from the } \\
\text { plant tissue on PDA }\end{array}$ & Roots & [89] \\
\hline S. indica* & T07-4, T07-1 & $\begin{array}{c}\text { Transplanting } \\
\text { substrate application } \\
\text { of mycelia }\end{array}$ & Light microscopy & Roots & [109] \\
\hline S. indica * & Nutech & $\begin{array}{c}\text { Seed coating } \\
\text { (bioformulation) }\end{array}$ & & Roots & [90] \\
\hline S. indica* & Vellayani Vijay & $\begin{array}{c}\text { Transplanting } \\
\text { substrate application } \\
\text { of mycelia }\end{array}$ & Light microscopy & Roots & [25] \\
\hline
\end{tabular}


Table 2. Cont.

\begin{tabular}{|c|c|c|c|c|c|}
\hline Fungal Species & Tomato Cultivar & $\begin{array}{l}\text { Method of EF } \\
\text { Inoculation }\end{array}$ & Detection Method & $\begin{array}{l}\text { Location of EF in } \\
\text { Plant Tissues }\end{array}$ & Ref. \\
\hline $\begin{array}{c}\text { Pochonia } \\
\text { chlamydosporia }\end{array}$ & Durinta & $\begin{array}{l}\text { Plating of seedlings } \\
\text { on fungal plate } \\
\text { cultures }\end{array}$ & $\begin{array}{c}\text { laser-scanning } \\
\text { confocal microscopy } \\
\text { PCR }\end{array}$ & Roots & [83] \\
\hline P. chlamydosporia & Marglobe & $\begin{array}{l}\text { Seed germination on } \\
\text { fungal plate cultures }\end{array}$ & $\begin{array}{l}\text { Re-isolation from the } \\
\text { plant tissue on CMA } \\
\text { PCR }\end{array}$ & Roots & [102] \\
\hline Pythium oligandrum & Micro-Tom & Root dipping & $\begin{array}{l}\text { laser scanning } \\
\text { microscopy }\end{array}$ & Roots & [110] \\
\hline P. oligandrum & Prisca & $\begin{array}{l}\text { Mycelial plugs in } \\
\text { proximity of the top } \\
\text { root }\end{array}$ & $\begin{array}{l}\text { SEM } \\
\text { TEM }\end{array}$ & Roots & [92] \\
\hline P. oligandrum & Prisca & Soil watering & TEM & Roots & [111] \\
\hline Tricoderma atroviride & $\begin{array}{l}\text { Hellfrucht/JW } \\
\text { Frühstamm }\end{array}$ & Soil application & & Roots & [43] \\
\hline T. atroviride & $\begin{array}{c}\text { Corbarino, M82, } \\
\text { SM36, TA209 }\end{array}$ & Seed coating & & Roots & [94] \\
\hline T. hamatum & Ohio 8245 & Soil application & & Roots & [98] \\
\hline T. harzianum & $\begin{array}{c}\text { Corbarino, M82, } \\
\text { SM36, TA209 }\end{array}$ & Seed coating & & Roots & [94] \\
\hline T. harzianum & Moneymaker & Soil application & & Roots & [99] \\
\hline T. harzianum & Arka vikas & Soil watering & & Roots & [112] \\
\hline
\end{tabular}

* scientific names are different from those present in the articles cited due to taxonomic updates to the name presently use.

\section{Constitutive Endophytes of Tomato}

EF have been reported to have a crucial role in inducing plant host tolerance to stressful conditions [59], plant defense [32], and plant growth and development [125]. In all-natural or agricultural ecosystems, every plant is colonized by a diversity of soil-borne microorganisms as root endophytes, mycorrhizal fungi, and plant growth-promoting rhizobacteria. Moreover, the analysis of plant-endophyte associations in high-abiotic stress habitats revealed that at least some fungal endophytes confer habitat-specific stress tolerance to the host plants. Without the presence of the habitat-adapted fungal endophytes, these plants were unable to survive in their native habitats [126]. Thus, the naturally occurring EF constitute a poorly exploited resource, rich in terms of biodiversity, representing a pool of potentially beneficial fungi from which the selection of new strains may be obtained for useful applications in agriculture.

Seven studies focused on the naturally occurring EF of tomato and the data are summarized in Table 3. The constitutive EF were comprised of 24 different genera, among which the most represented are Trichoderma and Fusarium, which included 35 different fungal species. It is interesting to note that some of the fungi reported in Table 3 are commonly recognized as plant beneficial fungi, such as Trichoderma spp., N. solani, and Sarocladium implicatum (formerly Acremonium implicatum), while other species are known as plant pathogens, for example, Alternaria solani, Stemphilyum lycopersici and Albifimbria verrucaria. A. solani causes early blight of tomato, one of the common foliar diseases of tomato [127], S. lycopersici is the causal agent of leaf spot disease on pepino (Solanum muricatum) [128], and A. verrucaria produces small brown to black spots symptoms on the colonized leaves and stems [129]. Moreover, A. verrucaria is also known to be the responsible agent of mycotic keratitis, one of the major causes of ophthalmic morbidity and visual loss globally [130]. This highlights the importance of identifying EF to study their prospective utilization in agriculture, but also to understand the possible implications on human health.

An example of EF use for tomato improvement is provided by the work of Bogner and colleagues [32] that was conducted in five different counties of Kenya with the aim of identifying and characterizing the culturable endophytic mycobiota in the roots of tomato and screening different fungal endophytes for their biocontrol potential towards the root-knot nematode Meloidogyne incognita. A total of 76 fungal isolates were obtained, among which the most prevalent species associated with tomato roots were members of the F. oxysporum and N. solani species complexes. Bioassays 
demonstrated the ability of selected non-pathogenic fungal isolates to successfully reduce nematode penetration and subsequent galling, as well as decrease the reproduction capacity of the root-knot nematode M. incognita. Most isolates in the Trichoderma asperellum and F. oxysporum complex were able to reduce the root-knot nematode egg densities by $35-46 \%$ in comparison to the treatments with the nonfungal control and the other fungal isolates. Moreover, Tian and colleagues isolated an endophytic fungus from tomato root galls infected with M. incognita that was identified as S. implicatum based on morphological and molecular identification [131]. The biocontrol potential of S. implicatum culture filtrates was tested with the plant and nematodes in vitro, in pot and field experiments. Results from the in vitro test indicated that $96 \%$ of second-stage juveniles of $M$. incognita were killed after $48 \mathrm{~h}$. The fungal compounds were also able to suppress egg hatching, the formation of root galls, and reduce the nematode population in the soil.

These findings suggest that naturally occurring EF populations in the soil represent an underestimated and valuable source of microbial diversity with positive impacts on sustainable agricultural production, due to the possibility to reduce the use of chemical products, thus benefiting the environment and human health. Moreover, this highlights the importance of promoting the constitutive endophytic populations in the soil in order to obtain the effective threshold level for biological control of organisms that compromise plant health. Many studies have demonstrated that soil type and plant genotype are the two main variables that affect the establishment of fungal species in the soil community [132-134]. The cultivation system can also influence the microbial species in the soil, whereby fungal abundance was significantly higher in organically farmed fields than the populations found in conventionally farmed that used chemicals [32,132]. In order to successfully develop applications of plant-associated $\mathrm{EF}$ in sustainable agricultural production, further investigations are necessary to understand the mechanisms of action and the processes employed by the fungi to produce the beneficial effects, as well as to determine how they can be efficiently utilized in actual practices.

Table 3. Naturally occurring constitutive endophytes of tomato.

\begin{tabular}{|c|c|c|c|c|c|}
\hline Fungal Species & Tomato Cultivar & Main Results & $\begin{array}{l}\text { Location of EF in } \\
\text { Plant Tissues }\end{array}$ & Country & Ref. \\
\hline $\begin{array}{c}\text { Alternaria solani } \\
\text { Aspergillus sclerotiorum } \\
\text { Cochliobolus geniculatus } \\
\text { Curvularia lunata * } \\
\text { Fusarium nygamai } \\
\text { Fusarium sp. } \\
\text { Fusarium verticillioides } \\
\text { Stemphylium lycopersici } \\
\text { Trichoderma asperellum } \\
\text { Trichoderma lixii * }\end{array}$ & Moneymaker & $\begin{array}{l}\text { Biological control to the } \\
\text { rootknot nematode } \\
\text { Meloidogyne incognita }\end{array}$ & Root & Kenya & [32] \\
\hline Fusarium spp. & $\begin{array}{c}\text { Heinz } 9907 \\
\text { Gem } 611 \\
\text { Heinz } 3402 \\
\text { FL } 47 \\
\text { Mountain Fresh }\end{array}$ & No effects & $\begin{array}{l}\text { Roots } \\
\text { Crown } \\
\text { Stem }\end{array}$ & USA & [134] \\
\hline $\begin{array}{l}\text { Fusarium oxysporum } \\
\text { Fusarium fujikuroi } \\
\text { Neocosmospora solani * }\end{array}$ & Momotaro & No effects & Stem & Japan & [135] \\
\hline Ochroconis humicola * & Gohobi & $\begin{array}{l}\text { Improved plant growth } \\
\text { with organic nitrogen } \\
\text { sources }\end{array}$ & Root & Japan & [125] \\
\hline $\begin{array}{c}\text { Albifimbria verrucaria * } \\
\text { Fusarium spp. } \\
\text { Setophoma terrestris } \\
\text { Trichoderma } \mathrm{spp} \text {. }\end{array}$ & $\begin{array}{l}\text { Heinz } 1706 \\
\text { Moneymaker }\end{array}$ & No effects & Root & Northern Italy & [133] \\
\hline
\end{tabular}


Table 3. Cont.

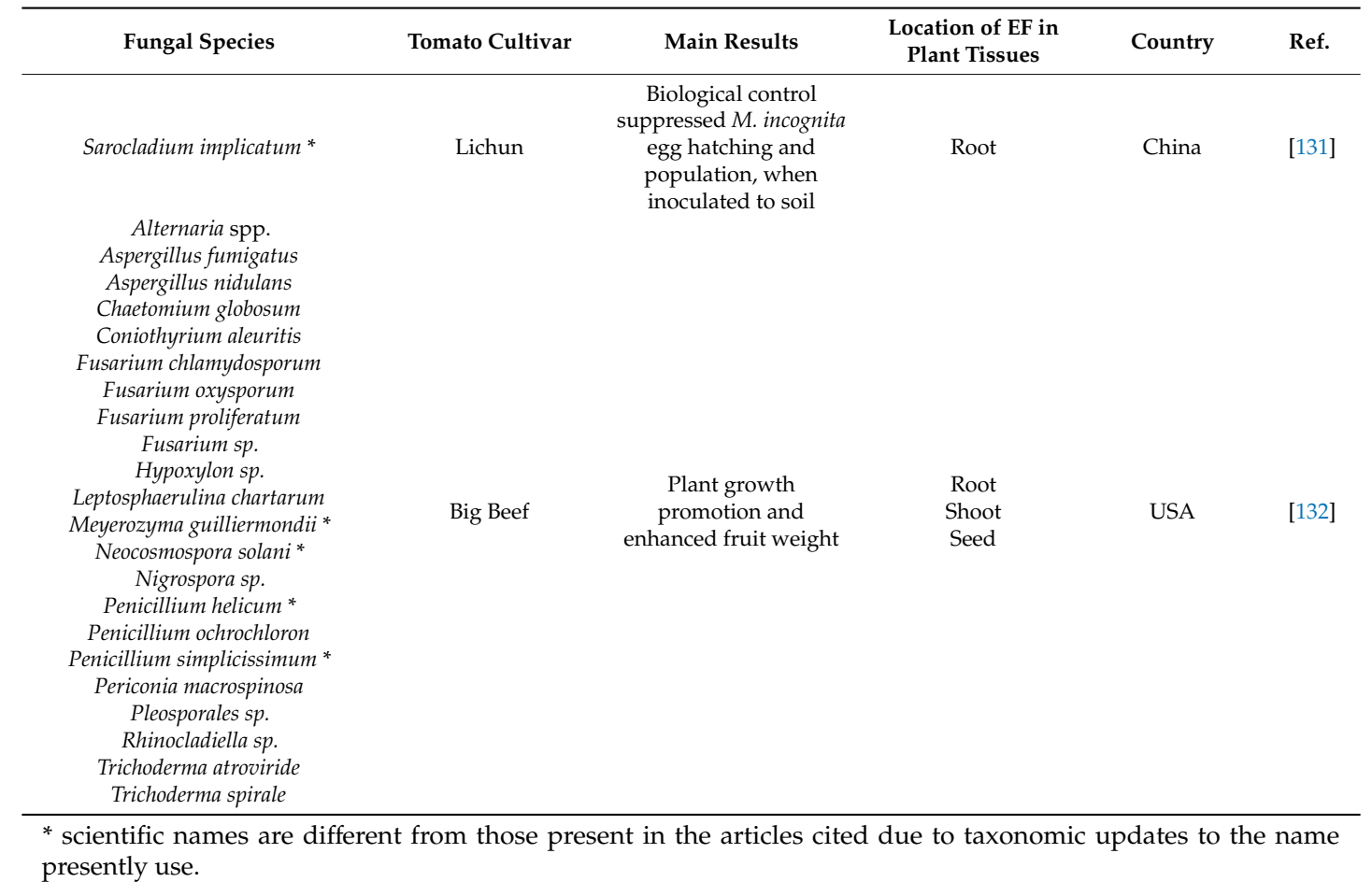

\section{Perspectives on EF Applications to Tomato}

EF are ubiquitous microorganisms in the natural and agricultural environment able to colonize plants internally.

In 1994, Dreyfuss and Chapela estimated that the global fungal diversity amounts to 1.5 million species, and based on their estimates, endophytic fungi alone could account for up to 1.3 million species [136]. This perspective on EF diversity was substantiated by subsequent studies of novel plant species, in particular, a study of the fungus:plant ratio in the tropical regions, confirmed that the number of 1.3 million endophytic fungi on the planet was a good assessment [137]. Recently, Hawksworth and Lücking revised the appraisal on global fungal diversity, concluding that the above-mentioned value was too conservative, and the actual range of fungal species should be considered at 2.2-3.8 million species [138].

Although the category of EF is gaining interest in the scientific community, due to their potentially beneficial applications, the studies conducted to date on this topic are still relatively limited and require further investigations.EF can be an extraordinary source of BCAs, PGP, and bioactive molecules, that can provide multiple positive effects to crops, which make them suitable components of biostimulants and biopesticides for use in agriculture [19,26,28]. Most endophytes are considered non-pathogenic, but not all are capable of producing plant beneficial effects [139]. Moreover, even when colonization occurs and positive effects are evident, the costs to the plant in hosting the endophyte/s have to be taken into account, an aspect that has not been studied extensively and is generally underestimated [136,140-143]. It should be considered that $\mathrm{EF}$ constitute a rich biodiversity source requiring a greater understanding of: (1) the mechanisms of action involved, those used by the fungal colonizer and the host plant, for crosstalk and recognition that permit the establishment of the interaction; (2) the ecological, biological, and physiological functions of the EF-plant relationship over time; plus (3) the factors and conditions that determine successful colonization [26,144,145].

Understanding the mechanisms underlying the plant-endophyte association and the subsequent outcomes, or the cause and effect, is fundamental for the advancement of EF know-how for the improvement of crop production. Currently, it is well recognized that the interaction between plant and 
endophyte is highly influenced by three factors: the genotype of the plant and its microbiome, the fungal genome, and the environmental conditions in which the association occurs [29]. Two major challenges became apparent during the preparation of this review, that in order to develop a wider use of EF in agriculture it will be necessary: (i) to determine how to select the best endophyte-plant combination and establish a stable long-lasting interaction between this beneficial microbe and the plant host targeted for improvement; and (ii) to prove the effectiveness of this technology outside of the controlled test conditions used to date, moving from the greenhouse to the actual open field environment.

Tomato plays host to a microbial community that is vast and highly variable, depending upon the prevailing environmental conditions and the plant genotype [132,144]. It could be interesting to concentrate investigations on the constitutive fungal endophytes that are native to the tomato plant, as they, by their inherent nature, represent a massive pool of highly "tomato-adapted" fungi. This vast fungal community represents a pool of biodiversity that up to now, has been poorly exploited in the strategies to discover highly adapted beneficial microbes of specific crops of interest. In general, a greater comprehension of the mechanisms that favor, along with those that hinder, the endophytic colonization of plants, is required for wider application of EF in agriculture [144]. For example, determine the environmental conditions known to be key factors for a successful EF-plant interaction $[26,132]$.

The artificial introduction of EF in agri-food crops also needs to be analyzed, to ascertain the possible risks that endophytic fungal colonization may present to the plant and the consumer, such as the introduction of potentially toxic metabolites (i.e., mycotoxins) to the food chain [144]. In this respect, studies should assess both the food safety of the fruits produced by EF-colonized plants, as well as evaluate the environmental effects in terms of the release or bioaccumulation of toxins in the soil or crop residues that may be a risk for the agroecosystem. Furthermore, an analysis of the outcome of the endophytic colonization on the organoleptic qualities of the agrifood products should also be taken into account.

In recent years, a growing number of studies have focused on the introduction of beneficial EF to tomato in order to exploit their biocontrol potential against pests and pathogens, as well as their growth promotion effect (references in this review). It is evident from the findings to date, that the introduction of EF represents a promising field of research and development, to which the consequences could determine a remarkable reduction of chemical use in agriculture. This outcome could be clearly observed in the field of crop protection, where it has already been well documented that the biocontrol activity of EF is able to limit the negative effects of several key tomato insect pests and pathogens, as well as nematodes. Moreover, the tomato plants harboring some EF have demonstrated enhanced tolerance to abiotic stress in the field, plus improvement in nutrient uptake, yield, and nutritional quality of the fruits.

This review reports that several EF species are good versatile BCA, controlling both pests and pathogens as demonstrated in the case of B. bassiana, F. oxysporum, N. solani, and T. harzianum, which are amenable candidates as plant beneficial microbes, also considering their additional properties as plant biostimulants. Nonetheless, a few surveyed papers considered the possibility to use EF species as a multi-use biocontrol agent, evaluating the simultaneous biocontrol of both pests and pathogens in tomato. Only recently, Jaber and Ownley underlined that some endophytic and entomopathogenic fungi conferred protection to their host plant not only against insect pests but also plant pathogens, and they proposed their use as dual biocontrol agents in agriculture [29]. Another interesting, potential application that has been poorly explored, is the possibility to use different EF species in a consortium and/or with other beneficial microbes. An example is given by the recent work of Varkey and colleagues which has proved that a consortium of rhizobacteria and fungal endophytes suppress the root-knot nematode in tomato [25]. Thus, the possibility to use EF as multiple biocontrol agents and the development of microbial consortia with synergistic beneficial effects on plant performance appears to be an interesting frontier that opens promising fields of research that deserve deeper investigations to better exploit the entire range of EF potential. 


\section{Conclusions}

In this review, we summarized the results obtained so far with the artificial introduction of EF in tomato and the subsequent beneficial effects that were observed. The main benefits to tomato plants are attributable to the biocontrol of several insect pests and plant pathogens, as well as their ability to improve plant performance. A focus on naturally occurring, constitutive EF of tomato was also undertaken, aimed at emphasizing their possible role in the selection of new beneficial strains for future use in tomato crop improvement. Moreover, an overview was conducted on the methods of introduction and detection of EF in tomato, providing a clear synthesis of the techniques used, that could be a practical guide to other researchers approaching this interesting field of research. The potential applications of endophytic fungi in horticultural production provide many advantages to the agroecosystem in terms of reducing chemical use and establishing a biological equilibrium necessary for the establishment of sustainable agriculture.

Author Contributions: Conceptualization, M.S., M.R., and S.L.W.; literature investigation M.S., M.R., G.d., and L.G.; writing-original draft preparation, M.S. and M.R.; writing-review and editing, S.L.W., project administration, S.L.W.; funding acquisition, S.L.W. All authors have read and agreed to the published version of the manuscript.

Funding: This research was funded by the following projects: European Union Horizon 2020 Research and Innovation Program, ECOSTACK (grant agreement no. 773554); fundings and a Ph.D. bursary to M.R. in PRIN 2017 [grant number PROSPECT 2017JLN833].

Acknowledgments: Thanks are due to Nadia Lombardi of the University of Naples, Federico II, for her editorial assistance.

Conflicts of Interest: The authors declare no conflict of interest.

\section{References}

1. Khan, S.; Guo, L.; Maimaiti, Y.; Mijit, M.; Qiu, D. Entomopathogenic Fungi as Microbial Biocontrol Agent. Mol. Plant. Breed. 2012, 3, 63-79. [CrossRef]

2. Gouda, S.; Das, G.; Sen, S.K.; Shin, H.S.; Patra, J.K. Endophytes: A treasure house of bioactive compounds of medicinal importance. Front. Microbiol. 2016, 7, 1538. [CrossRef] [PubMed]

3. Bamisile, B.S.; Dash, C.K.; Akutse, K.S.; Keppanan, R.; Afolabi, O.G.; Hussain, M.; Qasim, M.; Wang, L. Prospects of endophytic fungal entomopathogens as biocontrol and plant growth promoting agents: An insight on how artificial inoculation methods affect endophytic colonization of host plants. Microbiol. Res. 2018, 217, 34-50. [CrossRef]

4. McKinnon, A.C.; Saari, S.; Moran-Diez, M.E.; Meyling, N.V.; Raad, M.; Glare, T.R. Beauveria bassiana as an endophyte: A critical review on associated methodology and biocontrol potential. BioControl 2016, 62, 1-17. [CrossRef]

5. Ownley, B.H.; Gwinn, K.D.; Vega, F.E. Endophytic fungal entomopathogens with activity against plant pathogens: Ecology and evolution. BioControl 2010, 55, 113-128. [CrossRef]

6. Saikkonen, K.; Saari, S.; Helander, M. Defensive mutualism between plants and endophytic fungi? Fungal Divers. 2010, 41, 101-113. [CrossRef]

7. Young, C.A.; Hume, D.E.; McCulley, R.L. Forages and Pastures Symposium: Fungal endophytes of tall fescue and perennial ryegrass: Pasture friend or foe? J. Anim. Sci. 2013, 91, 2379-2394. [CrossRef]

8. Hyde, K.D.; Soytong, K. The fungal endophyte dilemma. Fungal Divers. 2008, 33, 163-173.

9. Parthasarathy, R.; Chandrika, M.; Rao, H.C.; Kamalraj, S.; Jayabaskaran, C.; Pugazhendhi, A. Molecular profiling of marine endophytic fungi from green algae: Assessment of antibacterial and anticancer activities. Process. Biochem. 2020, 96, 11-20. [CrossRef]

10. Jia, Q.; Qu, J.; Mu, H.; Sun, H.; Wu, C. Foliar endophytic fungi: Diversity in species and functions in forest ecosystems. Symbiosis 2020, 80, 102-132. [CrossRef]

11. Stone, J.K.; Bacon, C.W.; White, J.F., Jr. An overview of endophytic microbes: Endophytism defined. In Microbial Endophytes; White, J.F., Jr., Bacon, C.W., Eds.; Marcel Dekker Inc.: New York, NY, USA, 2000; pp. 3-29. 
12. Sherwood, M.; Carroll, G. Fungal succession on needles and young twigs of old-growth Douglas Fir. Mycologia 1974, 66, 499-506. [CrossRef]

13. Carroll, G. Fungal endophytes in stems and leaves: From latent pathogen to mutualistic symbiont. Ecology 1988, 69, 2-9. [CrossRef]

14. Stone, J.K.; Polishook, J.D.; White, J.F., Jr. Endophytic fungi. In Biodiversity of Fungi, Inventoring and Monitoring Methods; Mueller, G.M., Bills, G.F., Foster, M.S., Eds.; Elsevier: San Diego, CA, USA, 2004; pp. 241-270.

15. Krings, M.; Taylor, T.N.; Hass, H.; Kerp, H.; Dotzler, N.; Hermsen, E.J. Fungal endophytes in a 400-million-yr-old land plant: Infection pathways, spatial distribution, and host responses. New Phytol. 2007, 174, 648-657. [CrossRef] [PubMed]

16. Redecker, D.; Kodner, R.; Graham, L.E. Glomalean fungi from the Ordovician. Science 2000, 289, $1920-1921$. [CrossRef] [PubMed]

17. Petrini, O. Fungal endophytes of tree leaves. In Microbial Ecology of Leaves; Andrews, J.H., Hirano, S.S., Eds.; Springer: New York, NY, USA, 1991; pp. 179-197.

18. Jia, M.; Chen, L.; Xin, H.; Zheng, C.; Rahman, K.; Han, T. A friendly relationship between endophytic fungi and medicinal Plants: A systematic review. Front. Microbiol. 2016, 7, 1-14. [CrossRef] [PubMed]

19. Kusari, S.; Hertweck, C.; Spiteller, M. Chemical ecology of endophytic fungi: Origins of secondary metabolites. Chem. Biol. 2012, 19, 792-798. [CrossRef]

20. Lo Presti, L.; Lanver, D.; Schweizer, G.; Tanaka, S.; Liang, L.; Tollot, M.; Zuccaro, A.; Reissmann, S.; Kahmann, R. Fungal effectors and plant susceptibility. Annu. Rev. Plant. Biol. 2015, 66, 513-545. [CrossRef]

21. Saikkonen, K.; Faeth, S.H.; Helander, M.; Sullivan, T.J. Fungal endophytes: A continuum of interactions with host plants. Annu. Rev. Ecol. Syst. 1998, 29, 319-343. [CrossRef]

22. Wani, Z.A.; Ashraf, N.; Mohiuddin, T.; Riyaz-Ul-Hassan, S. Plant-endophyte symbiosis, an ecological perspective. Appl. Microbiol. Biotechnol. 2015, 99, 2955-2965. [CrossRef]

23. Resquín-Romero, G.; Garrido-Jurado, I.; Delso, C.; Ríos-Moreno, A.; Quesada- Moraga, E. Transient endophytic colonizations of plants improve the outcome of foliar applications of mycoinsecticides against chewing insects. J. Invertebr. Pathol. 2016, 136, 3-31. [CrossRef]

24. Kim, H.Y.; Choi, G.J.; Lee, H.B.; Lee, S.W.; Lim, H.K.; Jang, K.S.; Son, S.W.; Lee, S.O.; Cho, K.Y.; Sung, N.D.; et al. Some fungal endophytes from vegetable crops and their anti-oomycete activities against tomato late blight. Lett. Appl. Microbiol. 2007, 44, 332-337. [CrossRef] [PubMed]

25. Varkey, S.; Anith, K.N.; Narayana, R.; Aswini, S. A consortium of rhizobacteria and fungal endophyte suppress the root-knot nematode parasite in tomato. Rhizosphere 2018, 5, 38-42. [CrossRef]

26. Segaran, G.; Sathiavelu, M. Fungal endophytes: A potent biocontrol agent and a bioactive metabolites reservoir. Biocatal. Agric. Biotechnol. 2019, 21, 101284. [CrossRef]

27. Kumar, S.; Kaushik, N. Metabolites of endophytic fungi as novel source of biofungicide: A review. Phytochem. Rev. 2012, 11, 507-522. [CrossRef]

28. Bamisile, B.S.; Dash, C.K.; Akutse, K.S.; Keppanan, R.; Wang, L. Fungal endophytes: Beyond herbivore management. Front. Microbiol. 2018, 9, 1-11. [CrossRef]

29. Jaber, L.R.; Ownley, B.H. Can we use entomopathogenic fungi as endophytes for dual biological control of insect pests and plant pathogens? Biol. Control 2018, 116, 36-45. [CrossRef]

30. Glare, T.; Caradus, J.; Gelernter, W.; Jackson, T.; Keyhani, N.; Köhl, J.; Marrone, P.; Morin, L.; Stewart, A. Have biopesticides come of age? Trends Biotechnol. 2012, 30, 250-258. [CrossRef]

31. Knapp, S.; Peralta, I.E. The Tomato (Solanum lycopersicum L., Solanaceae) and its botanical relatives. In The Tomato Genome, Compendium of Plant Genomes; Causse, M., Giovannoni, J., Bouzayen, M., Zouine, M., Eds.; Springer: Berlin/Heidelberg, Germany, 2016; pp. 7-21.

32. Bogner, C.W.; Kariuki, G.M.; Elashry, A.; Sichtermann, G.; Buch, A.K.; Mishra, B.; Thines, M.; Grundler, F.M.W.; Schouten, A. Fungal root endophytes of tomato from Kenya and their nematode biocontrol potential. Mycol. Prog. 2016, 15, 30. [CrossRef]

33. Quesada-Moraga, E.; Muñoz-Ledesma, F.; Santiago-Alvarez, C. Systemic protection of Papaver somniferum L. against Iraella luteipes (Hymenoptera: Cynipidae) by an endophytic strain of Beauveria bassiana (Ascomycota: Hypocreales). Environ. Entomol 2009, 38, 723-730. [CrossRef]

34. Gurulingappa, P.; McGee, P.A.; Sword, G. Endophytic Lecanicillium lecanii and Beauveria bassiana reduce the survival and fecundity of Aphis gossypii following contact with conidia and secondary metabolites. Crop. Prot. 2011, 30, 349-353. [CrossRef] 
35. Sánchez-Rodríguez, A.R.; Raya-Díaz, S.; Zamarreño, Á.M.; García-Mina, J.M.; Del Campillo, M.C.; Quesada-Moraga, E. An endophytic Beauveria bassiana strain increases spike production in bread and durum wheat plants and effectively controls cotton leafworm (Spodoptera littoralis) larvae. Biol. Control 2018, 116, 90-102. [CrossRef]

36. Akello, J.; Sikora, R. Systemic acropedal influence of endophyte seed treatment on Acyrthosiphon pisum and Aphis fabae offspring development and reproductive fitness. Biol. Control 2012, 61, 215-221. [CrossRef]

37. Akutse, K.S.; Maniania, N.K.; Fiaboe, K.K.M.; Van den Berg, J.; Ekesi, S. Endophytic colonization of Vicia faba and Phaseolus vulgaris (Fabaceae) by fungal pathogens and their effects on the life-history parameters of Liriomyza huidobrensis (Diptera: Agromyzidae). Fungal Ecol. 2013, 6, 293-301. [CrossRef]

38. McGee, P. Reduced growth and deterrence from feeding of the insect pest Helicoverpa armigera associated with fungal endophytes from cotton. Aust. J. Exp. Agric. 2002, 42, 995-999. [CrossRef]

39. Vega, F.E. Insect pathology and fungal endophytes. J. Invertebr. Pathol. 2008, 98, 277-279. [CrossRef]

40. Lacey, L.A.; Neven, L.G. The potential of the fungus, Muscodor albus, as a microbial control agent of potato tuber moth (Lepidoptera: Gelechiidae) in stored potatoes. J. Invertebr. Pathol. 2006, 91, 195-198. [CrossRef] [PubMed]

41. Martinuz, A.; Schouten, A.; Sikora, R. Systemically induced resistance and microbial competitive exclusion: Implications on biological control. Phytopathology 2012, 102, 260-266. [CrossRef] [PubMed]

42. Barra-Bucarei, L.; Gerding, M. Antifungal Activity of Beauveria bassiana Endophyte against Botrytis cinerea in Two Solanaceae Crops. Microorganisms 2020, 8, 65. [CrossRef] [PubMed]

43. Menjivar, R.D.; Cabrera, J.A.; Kranz, J.; Sikora, R.A. Induction of metabolite organic compounds by mutualistic endophytic fungi to reduce the greenhouse whitefly Trialeurodes vaporariorum (Westwood) infection on tomato. Plant. Soil 2012, 352, 233-241. [CrossRef]

44. Gao, F.; Dai, C.; Liu, X. Mechanisms of fungal endophytes in plant protection against pathogens. Afr. J. Microbiol. Res. 2010, 4, 1346-1351.

45. Moy, M.; Belanger, F.; Duncan, R.; Freehoff, A.; Leary, C.; Meyer, W.; Sullivan, R.; White, J.F. JR. Identification of epiphyllous mycelial nets on leaves of grasses infected by Clavicipitaceous endophytes. Symbiosis 2000, 28, 291-302.

46. Conrath, U.; Beckers, G.J.M.; Flors, V.; Garcia-Agustin, P.; Jakab, G.; Mauch, F.; Newman, M.A.; Pieterse, C.M.J.; Poinssot, B.; Pozo, M.J.; et al. Priming: Getting ready for battle. Mol. Plant Microbe Interact. 2006, 19, 1062-1071. [CrossRef] [PubMed]

47. Dicke, M.; Van Loon, J.J.A.; Soler, R. Chemical complexity of volatiles from plants induced by multiple attack. Nat. Chem. Biol. 2009, 5, 317-324. [CrossRef] [PubMed]

48. Pieterse, C.M.J.; Poelman, E.H.; Van Wees, S.C.M.; Dicke, M. Induced plant responses to microbes and insects. Front. Plant. Sci. 2013, 4, 475. [CrossRef] [PubMed]

49. Poelman, E.H.; Bruinsma, M.; Zhu, F.; Weldegergis, B.T.; Boursault, A.E.; Jongema, Y.; van Loon, J.J.; Vet, L.E.; Harvey, J.A.; Dicke, M. Hyperparasitoids use herbivore-induced plant volatiles to locate their parasitoid host. PLoS Biol. 2012, 10, e1001435. [CrossRef]

50. Thakur, A.; Kaur, S.; Kaur, A.; Singh, V. Enhanced resistance to Spodoptera litura in endophyte infected cauliflower plants. Environ. Entomol. 2013, 42, 240-246. [CrossRef]

51. Manganiello, G.; Sacco, A.; Ercolano, M.R.; Vinale, F.; Lanzuise, S.; Pascale, A.; Napolitano, M.; Lombardi, N.; Lorito, M.; Woo, S.L. Modulation of tomato response to Rhizoctonia solani by Trichoderma harzianum and its secondary metabolite harzianic acid. Front. Microbiol. 2018, 9, 1966. [CrossRef]

52. Rodriguez, R.J.; White, J.F., Jr.; Arnold, A.E.; Redman, R.S. Fungal endophytes: Diversity and functional roles. New Phytol. 2009, 182, 314-330. [CrossRef]

53. Castillo Lopez, D.; Sword, G.A. The endophytic fungal entomopathogens Beauveria bassiana and Purpureocillium lilacinum enhance the growth of cultivated cotton (Gossypium hirsutum) and negatively affect survival of the cotton bollworm (Helicoverpa zea). Biol. Control. 2015, 89, 53-60. [CrossRef]

54. Jaber, L.R.; Enkerli, J. Effect of seed treatment duration on growth and colonization of Vicia faba by endophytic Beauveria bassiana and Metarhizium brunneum. Biol. Control 2016, 103, 187-195. [CrossRef]

55. Behie, S.W.; Zelisko, P.M.; Bidochka, M.J. Endophytic insect-parasitic fungi translocate nitrogen directly from insects to plants. Science 2012, 336, 1576-1577. [CrossRef]

56. Behie, S.W.; Bidochka, M.J. Nutrient transfer in plant-fungal symbioses. Trends Plant. Sci. 2014, 19, 734-740. [CrossRef] 
57. Nicoletti, R.; Becchimanzi, A. Endophytism of Lecanicillium and Akanthomyces. Agriculture 2020, $10,205$. [CrossRef]

58. Bills, G.F.; Polishook, J.D. Microfungi from Carpinus caroliniana. Can. J. Bot. 1991, 69, 1477-1482. [CrossRef]

59. Cherry, A.J.; Lomer, C.J.; Djegui, D.; Schulthess, F. Pathogen incidence and their potential as microbial control agents in IPM of maize stem borers in West Africa. BioControl 1999, 44, 301-327. [CrossRef]

60. Pimentel, I.C.; Glienke-Blanco, C.; Gabardo, J.; Stuart, R.M.; Azevedo, J.L. Identification and colonization of endophytic fungi from soybean (Glycine max (L.) Merril) under different environmental conditions. Braz. Arch. Biol. Technol 2006, 49, 705-711. [CrossRef]

61. Orole, O.O.; Adejumo, T.O. Activity of fungal endophytes against four maize wilt pathogens. Afr. J. Microbiol. Res. 2009, 3, 969-973.

62. Fuller-Schaefer, C.; Jung, K.; Jaronski, S. Colonization of sugarbeet roots by entomopathogenic fungi. In Proceedings of the 38th Annual Meeting of the Society for Invertebrate Pathology, Anchorage, AK, USA, 7-11 August 2005; Volume 49.

63. Greenfield, M.; Gómez-Jiménez, M.I.; Ortiz, V.; Vega, F.E.; Kramer, M.; Parsa, S. Beauveria bassiana and Metarhizium anisopliae endophytically colonize cassava roots following soil drench inoculation. Biol. Control 2016, 95, 40-48. [CrossRef]

64. Bing, L.A.; Lewis, L.C. Suppression of Ostrinia nubilalis (Hübner) (Lepidoptera: Pyralidae) by endophytic Beauveria bassiana (Balsamo) Vuillemin. Environ. Entomol. 1991, 20, 1207-1211. [CrossRef]

65. Bing, L.A.; Lewis, L.C. Endophytic Beauveria bassiana (Balsamo) Vuillemin in corn: The influence of the plant growth stage and Ostrinia nubilalis (Hübner). Biocontrol Sci. Technol. 1992, 2, 39-47. [CrossRef]

66. Wagner, B.L.; Lewis, L.C. Colonization of corn, Zea mays, by the entomopathogenic fungus Beauveria bassiana. Appl. Environ. Microbiol. 2000, 66, 3468-3473. [CrossRef]

67. Parsa, S.; Ortiz, V.; Vega, F.E. Establishing fungal entomopathogens as endophytes: Towards endophytic biological control. J. Vis. Exp. 2013, 74, 50360. [CrossRef]

68. Russo, M.L.; Pelizza, S.A.; Cabello, M.N.; Stenglein, S.A.; Scorsetti, A.C. Endophytic colonisation of tobacco, corn, wheat and soybeans by the fungal entomopathogen Beauveria bassiana (Ascomycota, Hypocreales). Biocontrol Sci. Technol. 2015, 25, 475-480. [CrossRef]

69. Prema Sundara Valli, P.; Muthukumar, T. Dark Septate Root Endophytic Fungus Nectria haematococca Improves Tomato Growth Under Water Limiting Conditions. Indian J. Microbiol. 2018, 58, 489-495. [CrossRef]

70. Vergara, C.; Araujo, K.E.C.; Urquiaga, S.; Schultz, N.; de Balieiro, F.C.; Medeiros, P.S.; Santos, L.A.; Xavier, G.R.; Zilli, J.E. Dark Septate endophytic fungi help tomato to acquire nutrients from ground plant material. Front. Microbiol. 2017, 8, 1-12. [CrossRef]

71. Yakti, W.; Kovács, G.M.; Vági, P.; Franken, P. Impact of dark septate endophytes on tomato growth and nutrient uptake. Plant. Ecol. Divers. 2018, 11, 637-648. [CrossRef]

72. Gurulingappa, P.; Sword, G.A.; Murdoch, G.; McGee, P.A. Colonization of crop plants by fungal entomopathogens and their effects on two insect pests when in planta. Biol. Control 2010, 55, 34-41. [CrossRef]

73. El-Deeb, H.M.; Lashin, S.M.; Arab, Y.A.S. Reaction of some tomato cultivars to tomato leaf curl virus and evaluation of the endophytic colonisation with Beauveria bassiana on the disease incidence and its vector, Bemisia tabaci. Arch. Phytopathol. Plant. Prot. 2012, 45, 1538-1545. [CrossRef]

74. Wei, Q.Y.; Li, Y.Y.; Xu, C.; Wu, Y.X.; Zhang, Y.R.; Liu, H. Endophytic colonization by Beauveria bassiana increases the resistance of tomatoes against Bemisia tabaci. Arthropod. Plant. Interact. 2020, 14, $289-300$. [CrossRef]

75. Qayyum, M.A.; Wakil, W.; Arif, M.J.; Sahi, S.T.; Dunlap, C.A. Infection of Helicoverpa armigera by endophytic Beauveria bassiana colonizing tomato plants. Biol. Control 2015, 90, 200-207. [CrossRef]

76. Prabhukarthikeyan, S.R.; Keerthana, U.; Archana, S.; Raguchander, T. Induced resistance in tomato plants to Helicoverpa armigera by mixed formulation of bacillus subtilis and Beauveria bassiana. Res. J. Biotechnol. 2017, 12, 53-59.

77. Garantonakis, N.; Pappas, M.L.; Varikou, K.; Skiada, V.; Broufas, G.D.; Kavroulakis, N.; Papadopoulou, K.K. Tomato inoculation with the endophytic strain Fusarium solani $\mathrm{K}$ results in reduced feeding damage by the zoophytophagous predator Nesidiocoris tenuis. Front. Ecol. Evol. 2018, 6, 1-7. [CrossRef] 
78. Shrivastava, G.; Ownley, B.H.; Augé, R.M.; Toler, H.; Dee, M.; Vu, A.; Köllner, T.G.; Chen, F. Colonization by arbuscular mycorrhizal and endophytic fungi enhanced terpene production in tomato plants and their defense against a herbivorous insect. Symbiosis 2015, 65, 65-74. [CrossRef]

79. Allegrucci, N.; Velazquez, M.S.; Russo, M.L.; Perez, E.; Scorsetti, A.C. Endophytic colonisation of tomato by the entomopathogenic fungus Beauveria bassiana: The use of different inoculation techniques and their effects on the tomato leafminer Tuta absoluta (Lepidoptera: Gelechiidae). J. Plant. Prot. Res. 2017, 57, 205-211. [CrossRef]

80. Klieber, J.; Reineke, A. The entomopathogenic Beauveria bassiana has epiphytic and endophytic activity against the tomato leafminer Tuta absoluta. J. Appl. Entomol. 2016, 140, 580-589. [CrossRef]

81. Dababat, A.E.F.A.; Sikora, R.A. Induced resistance by the mutualistic endophyte, Fusarium oxysporum strain 162, toward Meloidogyne incognita on tomato. Biocontrol Sci. Technol. 2007, 17, 969-975. [CrossRef]

82. Martinuz, A.; Schouten, A.; Sikora, R.A. Post-infection development of Meloidogyne incognita on tomato treated with the endophytes Fusarium oxysporum strain Fo162 and Rhizobium etli strain G12. BioControl 2013, 58, 95-104. [CrossRef]

83. Escudero, N.; Lopez-Llorca, L.V. Effects on plant growth and root-knot nematode infection of an endophytic GFP transformant of the nematophagous fungus Pochonia chlamydosporia. Symbiosis 2012, 57, 33-42. [CrossRef]

84. Bargmann, C.; Schönbeck, F. Acremonium kiliense as inducer of resistance to wilt diseases on tomatoes. J. Plant. Dis. Prot. 1992, 99, 266-272.

85. Culebro-Ricaldi, J.M.; Ruíz-Valdiviezo, V.M.; Rodríguez-Mendiola, M.A.; Ávila-Miranda, M.E.; GutiérrezMiceli, F.A.; Cruz-Rodríguez, R.I.; Dendooven, L.; Montes-Molina, J.A. Antifungal properties of Beauveria bassiana strains against Fusarium oxysporum f. sp. lycopersici race 3 in tomato crop. J. Environ. Biol. 2017, 38, 821-827. [CrossRef]

86. Aimé, S.; Alabouvette, C.; Steinberg, C.; Olivain, C. The endophytic strain Fusarium oxysporum Fo47: A good candidate for priming the defense responses in tomato roots. Mol. Plant Microbe Interact. 2013, 26, 918-926. [CrossRef] [PubMed]

87. Kavroulakis, N.; Ntougias, S.; Zervakis, G.I.; Ehaliotis, C.; Haralampidis, K.; Papadopoulou, K.K. Role of ethylene in the protection of tomato plants against soil-borne fungal pathogens conferred by an endophytic Fusarium solani strain. J. Exp. Bot. 2007, 58, 3853-3864. [CrossRef] [PubMed]

88. Nefzi, A.; Abdallah, R.A.B.; Jabnoun-Khiareddine, H.; Ammar, N.; Daami-Remadi, M. Ability of endophytic fungi associated with Withania somnifera L. to control Fusarium Crown and Root Rot and to promote growth in tomato. Braz. J. Microbiol. 2019, 50, 481-494. [CrossRef] [PubMed]

89. Fakhro, A.; Andrade-Linares, D.R.; von Bargen, S.; Bandte, M.; Büttner, C.; Grosch, R.; Schwarz, D.; Franken, P. Impact of Piriformospora indica on tomato growth and on interaction with fungal and viral pathogens. Mycorrhiza 2010, 20, 191-200. [CrossRef]

90. Sarma, M.V.R.K.; Kumar, V.; Saharan, K.; Srivastava, R.; Sharma, A.K.; Prakash, A.; Sahai, V.; Bisaria, V.S. Application of inorganic carrier-based formulations of fluorescent pseudomonads and Piriformospora indica on tomato plants and evaluation of their efficacy. J. Appl. Microbiol. 2011, 111, 456-466. [CrossRef] [PubMed]

91. Qiang, X.; Weiss, M.; Kogel, K.H.; Schäfer, P. Piriformospora indica a mutualistic basidiomycete with an exceptionally large plant host range. Mol. Plant. Pathol. 2012, 13, 508-518. [CrossRef] [PubMed]

92. Benhamou, N.; Rey, P.; Chérif, M.; Hockenhull, J.; Tirilly, Y. Treatment with the mycoparasite Pythium oligandrum triggers induction of defense-related reactions in tomato roots when challenged with Fusarium oxysporum f. sp. radicis-lycopersici. Phytopathology 1997, 87, 108-122. [CrossRef]

93. Azadi, N.; Shirzad, A.; Mohammadi, H. A study of some biocontrol mechanisms of Beauveria bassiana against Rhizoctonia disease on tomato. Acta Biol. Szeged. 2016, 60, 119-127.

94. Tucci, M.; Ruocco, M.; De Masi, L.; De Palma, M.; Lorito, M. The beneficial effect of Trichoderma spp. on tomato is modulated by the plant genotype. Mol. Plant. Pathol. 2011, 12, 341-354. [CrossRef]

95. Durrant, W.E.; Dong, X. Systemic acquired resistance. Ann. Rev. Phytopathol. 2004, 42, 185-209. [CrossRef]

96. Conrath, U.; Beckers, G.J.; Langenbach, C.J.; Jaskiewicz, M.R. Priming for enhanced defense. Ann. Rev. Phytopathol. 2015, 53, 97-119. [CrossRef]

97. Vos, C.M.; Yang, Y.; De Coninck, B.; Cammue, B.P.A. Fungal (-like) biocontrol organisms in tomato disease control. Biol. Control 2014, 74, 65-81. [CrossRef] 
98. Alfano, G.; Lewis Ivey, M.L.; Cakir, C.; Bos, J.I.B.; Miller, S.A.; Madden, L.V.; Kamoun, S.; Hoitink, H.A.J. Systemic modulation of gene expression in tomato by Trichoderma hamatum 382. Phytopathology 2007, 97, 429-437. [CrossRef]

99. Martínez-Medina, A.; Fernandez, I.; Lok, G.B.; Pozo, M.J.; Pieterse, C.M.J.; Van Wees, S.C.M. Shifting from priming of salicylic acid- to jasmonic acid-regulated defences by Trichoderma protects tomato against the root knot nematode Meloidogyne incognita. New Phytol. 2017, 213, 1363-1377. [CrossRef] [PubMed]

100. García, J.E.; Beatriz, P.J.; Alejandro, P.; Roberto, L.E. Metarhizium anisopliae (Metschnikoff) Sorokin promotes growth and has endophytic activity in tomato plants. Adv. Biol. Res. 2011, 5, 22-27.

101. Khan, A.L.; Waqas, M.; Hussain, J.; Al-Harrasi, A.; Hamayun, M.; Lee, I.J. Phytohormones enabled endophytic fungal symbiosis improve aluminum phytoextraction in tolerant Solanum lycopersicum: An examples of Penicillium janthinellum LK5 and comparison with exogenous $\mathrm{GA}_{3}$. J. Hazard. Mater. 2015, 295, 70-78. [CrossRef] [PubMed]

102. Zavala-Gonzalez, E.A.; Escudero, N.; Lopez-Moya, F.; Aranda-Martinez, A.; Exposito, A.; Ricaño-Rodríguez, J.; Naranjo-Ortiz, M.A.; Ramírez-Lepe, M.; Lopez-Llorca, L.V. Some isolates of the nematophagous fungus Pochonia chlamydosporia promote root growth and reduce flowering time of tomato. Ann. Appl. Biol. 2015, 166, 472-483. [CrossRef]

103. Sánchez-Rodríguez, A.R.; Del Campillo, M.C.; Quesada-Moraga, E. Beauveria bassiana: An entomopathogenic fungus alleviates Fe chlorosis symptoms in plants grown on calcareous substrates. Sci. Hortic. 2015, 197, 193-202. [CrossRef]

104. Khan, A.L.; Waqas, M.; Khan, A.R.; Hussain, J.; Kang, S.M.; Gilani, S.A.; Hamayun, M.; Shin, J.H.; Kamran, M.; Al-Harrasi, A.; et al. Fungal endophyte Penicillium janthinellum LK5 improves growth of ABA-deficient tomato under salinity. World J. Microbiol. Biotechnol. 2013, 29, 2133-2144. [CrossRef]

105. Vidal, S. Changes in suitability of tomato for whiteflies mediated by a non-pathogenic endophytic fungus. Entomol. Exp. Appl. 1996, 80, 272-274. [CrossRef]

106. Prabhukarthikeyan, R.; Saravanakumar, D.; Raguchander, T. Combination of endophytic Bacillus and Beauveria for the management of Fusarium wilt and fruit borer in tomato. Pest. Manag. Sci. 2014, 70, 1742-1750. [CrossRef] [PubMed]

107. Pappas, M.L.; Liapoura, M.; Papantoniou, D.; Avramidou, M.; Kavroulakis, N.; Weinhold, A.; Broufas, G.D.; Papadopoulou, K.K. The beneficial endophytic fungus Fusarium solani strain K alters tomato responses against spider mites to the benefit of the plant. Front. Plant. Sci. 2018, 9, 1-17. [CrossRef] [PubMed]

108. Kost, G.; Rexer, K. Morphology and Ultrastructure of Piriformospora indica. Soils Biol. 2013, 33, $25-36$. [CrossRef]

109. Wang, H.; Zheng, J.; Ren, X.; Yu, T.; Varma, A.; Lou, B.; Zheng, X. Effects of Piriformospora indica on the growth, fruit quality and interaction with Tomato yellow leaf curl virus in tomato cultivars susceptible and resistant to TYCLV. Plant. Growth Regul. 2015, 76, 303-313. [CrossRef]

110. Masunaka, A.; Nakaho, K.; Sakai, M.; Takahashi, H.; Takenaka, S. Visualization of Ralstonia solanacearum cells during biocontrol of bacterial wilt disease in tomato with Pythium oligandrum. J. Gen. Plant Pathol. 2009, 75, 281-287. [CrossRef]

111. Le Floch, G.; Vallance, J.; Benhamou, N.; Rey, P. Combining the oomycete Pythium oligandrum with two other antagonistic fungi: Root relationships and tomato grey mold biocontrol. Biol. Control 2009, 50, 288-298. [CrossRef]

112. Chowdappa, P.; Mohan Kumar, S.P.; Jyothi Lakshmi, M.; Upreti, K.K. Growth stimulation and induction of systemic resistance in tomato against early and late blight by Bacillus subtilis OTPB1 or Trichoderma harzianum OTPB3. Biol. Control 2013, 65, 109-117. [CrossRef]

113. Powell, W.A. Potential of Beauveria Bassiana 11-98 as a Biological Control Agent against Tomato Pests; and Detection of the Mycotoxic Metabolite Beauvericin in Tomato Plants Using HPLC. Master's Thesis, University of Tennessee, Knoxville, TN, USA, 2005.

114. Posada, F.; Aime, M.C.; Peterson, S.W.; Rehner, S.A.; Vega, F.E. Inoculation of coffee plants with the fungal entomopathogen Beauveria bassiana (Ascomycota: Hypocreales). Mycol. Res. 2007, 111, 748-757. [CrossRef]

115. Biswas, C.; Dey, P.; Satpathy, S.; Satya, P.; Mahapatra, B. Endophytic colonization of white jute (Corchorus capsularis) plants by different Beauveria bassiana strains for managing stem weevil (Apion corchori). Phytoparasitica 2013, 41, 17-21. [CrossRef] 
116. Landa, B.B.; López-Díaz, C.; Jiménez-Fernández, D.; Montes-Borrego, M.; Muñoz-Ledesma, F.J.; Ortiz-Urquiza, A.; Quesada-Moraga, E. In-planta detection and monitorization of endophytic colonization by a Beauveria bassiana strain using a new-developed nested and quantitative PCR-based assay and confocal laser scanning microscopy. J. Invertebr. Pathol. 2013, 114, 128-138. [CrossRef]

117. Renuka, S.; Ramanujam, B.; Poornesha, B. Endophytic ability of different isolates of entomopathogenic fungi Beauveria bassiana (Balsamo) Vuillemin in stem and leaf tissues of maize (Zea mays L.). Indian J. Microbiol 2016, 56, 126-133. [CrossRef] [PubMed]

118. Garrido-Jurado, I.; Resquín-Romero, G.; Amarilla, S.P.; Ríos- Moreno, A.; Carrasco, L.; Quesada-Moraga, E. Transient endophytic colonization of melon plants by entomopathogenic fungi after foliar application for the control of Bemisia tabaci Gennadius (Hemiptera: Aleyrodidae). J. Pest. Sci. 2017, 90, 319-330. [CrossRef]

119. Rondot, Y.; Reineke, A. Endophytic Beauveria bassiana in grapevine Vitis vinifera (L.) reduces infestation with piercing-sucking insects. Biol. Control 2018, 116, 82-89. [CrossRef]

120. Nishi, O.; Sushida, H.; Higashi, Y.; Iida, Y. Epiphytic and endophytic colonisation of tomato plants by the entomopathogenic fungus Beauveria bassiana strain GHA. Mycology 2020, 11, 1-9. [CrossRef]

121. Krell, V.; Jakobs-Schoenwandt, D.; Vidal, S.; Patel, A.V. Encapsulation of Metarhizium brunneum enhances endophytism in tomato plants. Biol. Control 2018, 116, 62-73. [CrossRef]

122. Jallow, M.F.A.; Dugassa-Gobena, D.; Vidal, S. Influence of an endophytic fungus on host plant selection by a polyphagous moth via volatile spectrum changes. Arthropod. Plant. Interact. 2008, 2, 53-62. [CrossRef]

123. Omukoko, C.A. Biocontrol Mechanisms of Endophytic Beauveria bassiana in Three Tomato (Lycopersum esculentum) Varieties C. World Dev. 2018, 1, 43-52. [CrossRef]

124. Omukoko, C.A.; Turoop, L. Colonization of Tomato Varieties by Beauveria bassiana Isolates in the Screen House. Int. J. Sci. Res. 2017, 6, 1024-1028. [CrossRef]

125. Mahmoud, R.S.; Narisawa, K. A new fungal endophyte, Scolecobasidium humicola, promotes tomato growth under organic nitrogen. PLoS ONE 2013, 8, 1-8. [CrossRef]

126. Rodriguez, R.; Redman, R. More than 400 million years of evolution and some plants still can't make it on their own: Plant stress tolerance via fungal symbiosis. J. Exp. Bot. 2008, 59, 1109-1114. [CrossRef]

127. Fritz, M.; Jakobsen, I.; Lyngkjær, M.F.; Thordal-Christensen, H.; Pons-Kühnemann, J. Arbuscular mycorrhiza reduces susceptibility of tomato to Alternaria solani. Mycorrhiza 2006, 16, 413-419. [CrossRef] [PubMed]

128. Nasehi, A.; Kadir, J.; Nasr-Esfahani, M.; Abed-Ashtiani, F.; Golkhandan, E.; Ashkani, S. Identification of the New Pathogen (Stemphylium lycopersici) Causing Leaf Spot on Pepino (Solanum muricatum). J. Phytopathol. 2016, 164, 421-426. [CrossRef]

129. Gilardi, G.; Matic, S.; Luongo, I.; Gullino, M.L.; Garibaldi, A. First Report of Stem Necrosis and Leaf Spot of Tomato Caused by Albifimbria verrucaria in Italy. Plant. Dis. 2020, 4, 2026. [CrossRef]

130. Rameshkumar, G.; Sikha, M.; Ponlakshmi, M.; Selva Pandiyan, A.; Lalitha, P. A rare case of Myrothecium species causing mycotic keratitis: Diagnosis and management. Med. Mycol. Case Rep. 2019, 25, 53-55. [CrossRef]

131. Tian, X.; Yao, Y.; Chen, G.; Mao, Z.; Wang, X.; Xie, B. Suppression of Meloidogyne incognita by the endophytic fungus Acremonium implicatum from tomato root galls. Int. J. Pest. Manag. 2014, 60, 239-245. [CrossRef]

132. Xia, Y.; Sahib, M.R.; Amna, A.; Opiyo, S.O.; Zhao, Z.; Gao, Y.G. Culturable endophytic fungal communities associated with plants in organic and conventional farming systems and their effects on plant growth. Sci. Rep. 2019, 9, 1-10. [CrossRef]

133. Poli, A.; Lazzari, A.; Prigione, V.; Voyron, S.; Spadaro, D.; Varese, G.C. Influence of plant genotype on the cultivable fungi associated to tomato rhizosphere and roots in different soils. Fungal Biol. 2016, 120, 862-872. [CrossRef]

134. Demers, J.E.; Gugino, B.K.; del Mar Jiménez-Gasco, M. Highly diverse endophytic and soil Fusarium oxysporum populations associated with field-grown tomato plants. Appl. Environ. Microbiol. 2015, 81, 81-90. [CrossRef]

135. Imazaki, I.; Kadota, I. Molecular phylogeny and diversity of Fusarium endophytes isolated from tomato stems. FEMS Microbiol. Ecol. 2015, 91,1-16. [CrossRef]

136. Dreyfuss, M.M.; Chapela, I.H. Potential of fungi in the discovery of novel, low-molecular weight pharmaceuticals. Biotechnology 1994, 26, 49-80. [CrossRef]

137. Hawksworth, D.L. The magnitude of fungal diversity: The 1.5 million species estimate revisited. Mycol. Res. 2001, 105, 1422-1432. [CrossRef] 
138. Hawksworth, D.L.; Lücking, R. Fungal Diversity Revisited: 2.2 to 3.8 Million Species. Microbiol Spectr. 2017, 5, 79-95. [CrossRef]

139. Kuldau, G.A.; Yates, I.E. Evidence for Fusarium endophytes in cultivated and wild plants. In Microbial Endophytes; Bacon, C.W., White, J.F., Eds.; Marcel Dekker: New York, NY, USA, 2000; pp. 85-117.

140. Carroll, G.C. Beyond pest deterrence-Alternative strategies and hidden costs of endophytic mutualisms in vascular plants. In Microbial Ecology of Leaves; Andrews, J.H., Hirano, S.S., Eds.; Springer: New York, NY, USA, 1991; pp. 358-375.

141. Clay, K.; Schardl, C. Evolutionary origins and ecological consequences of endophyte symbiosis with grasses. Am. Nat. 2002, 160, S99-S127. [CrossRef] [PubMed]

142. Davitt, A.J.; Stansberry, M.; Rudgers, J.A. Do the costs and benefits of fungal endophyte symbiosis vary with light availability? New Phytol. 2010, 188, 824-834. [CrossRef]

143. Suryanarayanan, T.S. Endophyte research: Going beyond isolation and metabolite documentation. Fungal Ecol. 2013, 6, 561-568. [CrossRef]

144. Vega, F.E. The use of fungal entomopathogens as endophytes in biological control: A review. Mycologia 2018, 110, 4-30. [CrossRef]

145. De Silva, N.I.; Brooks, S.; Lumyong, S.; Hyde, K.D. Use of endophytes as biocontrol agents. Fungal Biol. Rev. 2019, 33, 133-148. [CrossRef]

Publisher's Note: MDPI stays neutral with regard to jurisdictional claims in published maps and institutional affiliations.

(C) 2020 by the authors. Licensee MDPI, Basel, Switzerland. This article is an open access article distributed under the terms and conditions of the Creative Commons Attribution (CC BY) license (http://creativecommons.org/licenses/by/4.0/). 